\title{
Co-operative Decision Making Structure and Its Effectiveness in Promoting Sustainable Co-operative Organizations in Tanzania: A Case of Selected Agricultural Marketing Co-operatives in Shinyanga Region
}

Gratian Cronery Rwekaza* and Paulo Anania

Department of Co-operative Development and Management, Moshi Co-operative University (MoCU), United Republic of Tanzania

\begin{abstract}
The effectiveness of decision making is a pivotal in the cooperative institution, the question of who should make decisions is by protocol vested to members. This paper is dedicated to on the assessing the tragedy of decision making structure in the cooperative, guided by objectives which are; to determine the structure of decision making and governance, assessing the effectiveness of the co-operative structure in decision and assess the effectiveness of the feedback system in agricultural marketing co-operatives in Tanzania. The study draws evidence from the selected agricultural marketing cooperative in Shinyanga; there the case study design was employed. The findings revealed that; member decision is hijacked by external drive who controls the cooperatives, meeting are called by either unions or cooperative officers that indicates, it is not from members wishes. And the cooperatives lacks feedback mechanism to feed members on the decision made, that brings gap between management, board and members. The study concluded that, cooperative are for members but members do hold their institutions. Generally the study recommends the review of cooperative law, rules and guidelines that will reflect member ownership in decisions, also the supervisory committee be established in the primary societies to enlarge managerial accountability.
\end{abstract}

Keywords: Agricultural marketing cooperative; Decision making structure; Member ownership

\section{Introduction}

\section{Background information}

Co-operatives in Africa are omnipresent, and they represent the larger population thus, they are used as a tool for uniting the marginalized from the social and economic setup. During that period, cooperatives in Africa were used by the colonial powers as a strategic tool to group rural producers into clusters, so that essential export commodities such as coffee, cocoa and cotton, could be collected more cost-effectively [1-3]. After independence, the governments of the currently sovereign states accorded an essential role to cooperatives, in particular for the development of rural areas. Co-operatives enjoyed preferential treatment and were granted supply and marketing monopolies which protected them from competition CRMP [4]. They paid for these privileges with the total loss of autonomy, democratic control and business efficiency. Co-operatives degenerated into tools of government.

In Tanzania, there are numerous co-operative institutions in almost all sectors of social and economic structures. A number of researchers have contributed in the understanding of relations that exists between co-operative member and decision making in co-operative [3]. Sizya provide the status of co-operative representative institutions in decision making organs, in his description he explains that the Government has given co-operatives a place in the Policy making machinery [5]. He further noted that, the Apex which as of now, there is a use of cooperative federations where co-operative organizations are represented and also established to bring in all stakeholders in the policy making process. Though, given the weak status of the co-operatives and particularly the apex co-operatives which was removed by the new Tanzanian Co-operative Society Act of 2014, this representation is yet to be effectively utilized to bring up the voice of the rural poor whom the co-operative structures are indeed to be representing in the cooperative governance. That was also emphasized in the Ujamaa villages Act of 1975 [6].
Similarly representatives from the co-operative movement included on the Boards of the statutory Marketing boards" but do these really represents members? Are the structures of information flow in place? Do members know what will be presented on their behalf? All this were identified in this study and was presented in the fourth chapter. The Similar result were reported by Komba [7] who argued that, co-operative member control and member participation can be expressed under co-operative mission under the liberalized economic environment that recognizes co-operatives as among many business players in the market. Komba and Leonard et al. [1,7] further noted that, co-operatives need economically strong organizations at the grassroots that are created through different groups of small producers to build up resource capacity, to efficiently conduct their business activities and withstand competition from other players in the market, through cooperative missions, how far had the co-operative institutions address the aspect of member mainstreaming on the process of forming these missions. These become a point to advocate for having sound cooperative institutions.

Sizya and Moshi explain that co-operative members that are the client of the co-operative institution $[4,8]$. Because of dual relationship within a co-operative, there is a possibility of member disloyalty towards the institutions. He concluded that, the management of such an institution is required to address the issue of member loyalty for

*Corresponding author: Gratian Cronery Rwekaza, Department of Management, Moshi Co-operative University (MoCU), United Republic of Tanzania, Tel: +255 27 275 4401; E-mail: gcronery@yahoo.com

Received December 07, 2017; Accepted January 03, 2018; Published January 10, 2018

Citation: Rwekaza GC, Anania P (2018) Co-operative Decision Making Structure and Its Effectiveness in Promoting Sustainable Co-operative Organizations in Tanzania: A Case of Selected Agricultural Marketing Co-operatives in Shinyanga Region. Arts Social Sci J 9: 320. doi: 10.4172/2151-6200.1000320

Copyright: (c) 2018 Rwekaza GC, et al. This is an open-access article distributed under the terms of the Creative Commons Attribution License, which permits unrestricted use, distribution, and reproduction in any medium, provided the original author and source are credited. 
Citation: Rwekaza GC, Anania P (2018) Co-operative Decision Making Structure and Its Effectiveness in Promoting Sustainable Co-operative Organizations in Tanzania: A Case of Selected Agricultural Marketing Co-operatives in Shinyanga Region. Arts Social Sci J 9: 320. doi: $10.4172 / 2151-6200.1000320$

Page 2 of 5

achieving efficiency and short of that the clients of a co-operative can look out for products or service of outside competitor. Rwekaza and Muhihi and Chambo provide the status of African co-operatives that continue to be producer of raw material but trading with industrialized countries [3,9]. The later groups of countries, which have the capacity of nationalization on the economic utilization of imported raw materials from the developing world, remain dominant. As result of this position Africa continue to occupy a weak bargaining position when it comes to trade bargaining participation.

In that regard we need co-operative governance that is member focused. According to Copa, Anania and Rwekaza contend that co-operative governance has primary aims of providing sufficient transparency, control and guidance to members $[3,10]$. Members are the user-members and controller of the co-operative to ensure that all decisions, actions and services provided by the management and executives of the co-operative, is in line with the interests of members. This is due to the fact that, members are the users of the co-operatives services. A study by Komba explained the aspect of The Co-operative Development Policy 2002 applicability in the co-operative institutions. In that he contended that "the Vision or direction of Co-operative System in Tanzania is geared towards improved and sustainable cooperatives that are capable of fulfilling members' economic and social needs [5]. This was supported by Chavez when explains the aspect of co-operative member driven model that had operated in the Canadian aborigines, that co-operatives members have established artisan cooperatives that provide the world with artwork, this was possible through a model of co-operatives that is owned by the cooperators in all dimensions [11].

\section{Problem statement}

Tanzania acknowledged the development potential of cooperatives towards its efforts in poverty reduction and uniting efforts of the marginalized. The cooperatives are structured in a way that the members becomes the owners, and they were vested all the decision rights through their general meetings. Reports on their failure were abundant especially because cooperatives were introduced in Africa as a foreign model specifically designed for colonial purposes. Such imprints has made the owners not enjoying the decisions rights as its still made by the peripheral, that is; the Government, Union, Manages, cooperative promoters who are not owners.

\section{Research objectives}

The study was guided by the main objective that was to "determine the effectiveness and challenges of the co-operative decision making structure in agricultural marketing co-operatives in Tanzania", drawing evidence from agricultural marketing cooperatives from Shinyanga region. The underlying specific objectives were:

(i) To determine the structure of decision making in governance of agricultural marketing co-operatives,

(ii) To assess the effectiveness of the co-operative structure in decision making in agricultural marketing co-operatives, and

(iii) To assess the effectiveness of the feedback system in agricultural marketing co-operatives.

\section{Significance of the study}

This paper provides a practical experience on the effectiveness and challenges of the decision making structure and related processes in the agricultural marketing co-operatives in Tanzania. This study is expected to provide scholars, co-operative members and other stakeholders in the co-operative movement with an understanding and capacity to make reflection on matters relating to the decision making structure in agricultural marketing co-operatives. The lessons learnt from this study give a foundation for initiatives to restructure various processes and relationship among members in the co-operative organizational structure so as to further cultivate good governance, ensure effective decision making structures and set better mechanism for providing feedback to the membership. The finding may also be useful to other self-help groups like farmers associations and other local community organizations which are members-based.

\section{Methodology}

This paper was written based on the study conducted in Shinyanga region, Tanzania where its residents are engaging in different agricultural crops, both food and commercial cultivation. The agricultural marketing co-operatives used in this study were from three wards of Ibadakuli, Uzogole and Kizumbi where members produce cotton. The study area was chosen due to two reasons. First, Shinyanga is among the ancient giant co-operative institutions; secondly, the aspect of co-operative governance in Shinyanga co-operatives was not been researched yet while the members that have long experience in the agricultural marketing co-operatives that can provide feasible experience. The cross sectional study design was used in this study. Also both qualitative and quantitative approaches were applied in the analysis. In sampling, both the simple random and purposive sampling methods were applied. Simple random sampling was applied to a sample of members to respond for the questions given in this study. The purposive sampling was used in obtaining the primary and union co-operative board members, management personnel, non-members and the co-operative officers. A sample of 100 respondents was drawn for this research study as shown in Table 1 .

The study collected both primary and secondary data. The primary data were collected through three main methods of; interview, survey (using questionnaire) and observation. Documentary review was used to gather secondary data where a review was done on the files of minutes of various meetings and reports of the studied co-operatives, Shinyanga Region Co-operative Union (SHIRECU) as well as the Cooperative department in Shinyanga. The by-laws and polices were also reviewed to see how they guide members' participation in co-operatives. The analysis of the collected data was assisted by using two computer softwares namely; Statistical Package for Social Science (SPSS) and Microsoft Excel. The reason being that, these tools of analysis fits into the nature of the collected data hence helped in attaining the objectives of the research study.

\section{Analysis and Discussion}

This chapter present the findings obtained from agricultural marketing co-operative societies, co-operative departments, general

\begin{tabular}{|l|c|}
\hline Categories of respondents & Number \\
\hline Co-operative Board members & 10 \\
\hline Co-operative management & 03 \\
\hline Ordinary members & 67 \\
\hline Co-operative officers & 3 \\
\hline Co-operative Union officers & 5 \\
\hline Non co-operative members & 07 \\
\hline Total & 100 \\
\hline Source: Field data & \\
\hline
\end{tabular}

Table 1: Sample size categories. 
Citation: Rwekaza GC, Anania P (2018) Co-operative Decision Making Structure and Its Effectiveness in Promoting Sustainable Co-operative Organizations in Tanzania: A Case of Selected Agricultural Marketing Co-operatives in Shinyanga Region. Arts Social Sci J 9: 320. doi: $10.4172 / 2151-6200.1000320$

Page 3 of 5

public and Shinyanga Region Co-operative Union (SHIRECU) in Shinyanga. The key respondents of this study were the co-operative members engaging in cotton farming (though they grow other crops such as maize, sunflower, millet and groundnuts). The entire cooperative members and the Board members interviewed were having primary school education (Standard VII) that also was reported by Rwekaza and Nko, Anania and Rwekaza [12,13]. The co-operative management had ordinary secondary school certificate graduates. The focus of the study was on examining the structure of decision making by members in co-operative societies.

\section{Decision making structures in the co-operative organization}

The decision making structure in co-operative was found to be an interplay among various structures or organs in the co-operative organization. The key actors in co-operative decision making are the internal stakeholders who are; the annual general meeting (AGM) of all members, the Board (and its supporting committees) and the employed staffs (manager and his/her assistant staff).

Each stakeholder at various situations has a right to make certain decision but should not contradict with the existing by-laws, policies, regulation and laws and well as interests of majority of members. In term of hierarchy, members are put at the top of the structure as the one who are making all the final decisions for their co-operative and the Board, committees and management should accept, adhere and implement such decision. As Chambo and Diyamett, argued that members have granted some authority to the Board to make and implement some decision on their behalf. Similarly the management is given authority to make some managerial and other decisions but should be approved by the member or Board on behalf $[14,15]$.

The study found that $85 \%$ of respondents indicated that the annual general meeting (AGM) that consists of ordinary members are the most powerful in decision making and they are assigning some authorities to their Board to make and implement some decisions on their behalf while $15 \%$ indicated that the Board is the most powerful organ in making decisions. Although this response is seen small but may raise a question as to why in some cases the Board. In assessing whether the manager is given authority to make decision, $70 \%$ agreed that in their co-operative managers are given some rights to make and implement decisions, mostly relating to day to day operation but for the major decisions they should consult the Board and where necessary the members. The remained $30 \%$ responded that their managers are following decisions made by their Board or ordinary members.

\section{The effectiveness of structures of decision making in the co- operative governance}

In this part, the bases were to assess decision making aspect in cooperative governance. We had found some conflicting understanding between theory and practice. The findings indicate low members knowledge of the structure of decision making in their co-operative. In examining the understanding of the organ that is responsible for decision making, it indicates members understanding on the decision making organ in the co-operative societies. The findings were as follows in Figure 1.

In these findings it is indicated that $47 \%$ of respondents accepting that the decisions are to be made at the annual general meeting (AGM). That becomes contrary since some general meetings are called after enforcement from the co-operative department. That call for impinging the participation of members since, meetings are not called at the wishes of the members, taking the case of Kizumbi AMCOS annual general meeting held by 25 May, 2012, and 16 April 2015 was called in responding of the demand of the co-operative department with letter dated 15 March, 2012 Ref No CD.62/95/01/63 and basing on the schedule directed with the letter dated 30 March, 2012 Ref No SHY/MC/0/40 and Ref No CD.62/95/02/16 dated March 2015 And that provides directives made by the co-operative departments as government directives makes AMCOS to have the annual general meeting. And this was the practice in all the surveyed three AMCOS.

In this regard, Solomon argued that, member participation in co-operatives is full of ambiguity. The study found having higher percentage of importance of AGM as organ in decision making, but still there is very low participation despite the fact that, members understanding the viability of member participation at the AGM [14] The independence and autonomous co-operatives are the key aspect for co-operative prosperity. In the report by ICA indicated that, cooperative institutions needs to be autonomous and independent from the external controls. The co-operative autonomous sometimes were found to be impinged by the government intervention when they enforce the co-operative institutions to call meeting more externally driven than mobilizing internal driven model for calling the meetings. Also Lema and Mfangavo presented the aspect of co-operative to be like babies that do not know what to do and what to decide $[16,17]$. This makes the co-operative institutions to remain dependent to the government in making decision of the co-operative affairs.

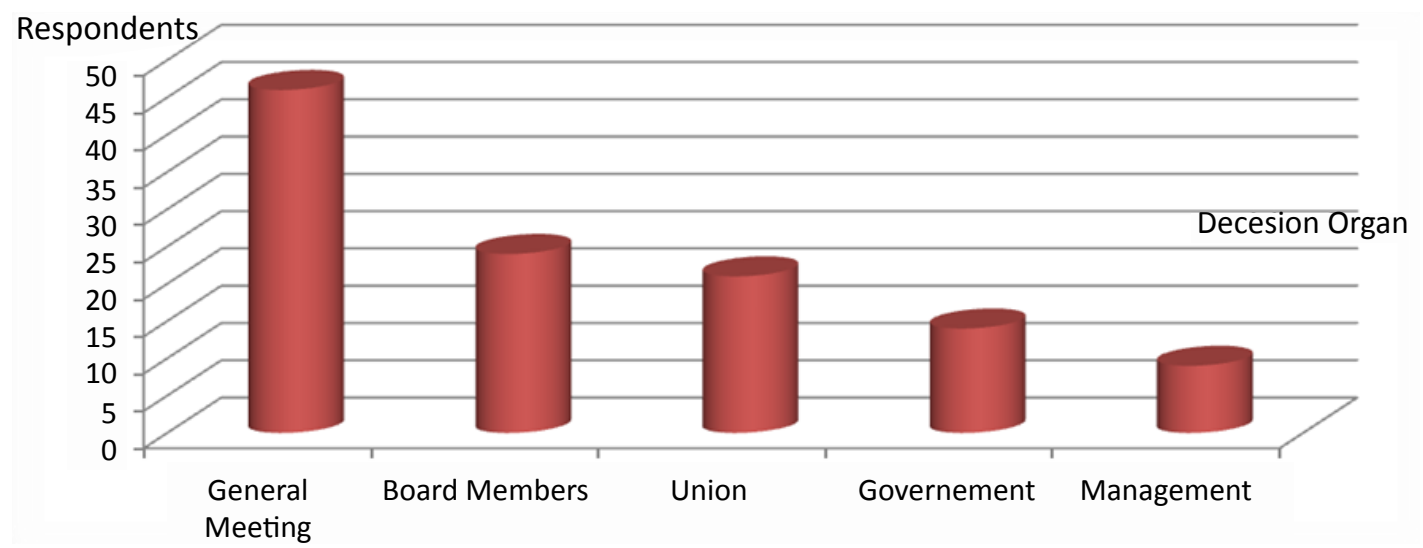

Figure 1: The decision making organ in the AMCOS. 
Citation: Rwekaza GC, Anania P (2018) Co-operative Decision Making Structure and Its Effectiveness in Promoting Sustainable Co-operative Organizations in Tanzania: A Case of Selected Agricultural Marketing Co-operatives in Shinyanga Region. Arts Social Sci J 9: 320. doi: $10.4172 / 2151-6200.1000320$

Page 4 of 5

\section{The effectiveness of feedback system in co-operative governance}

The feedback to what had been agreed on the co-operative general meetings, and co-operative decision, found not to be in place on the surveyed AMCOS. The research found out that co-operative members do not receive feedback. This means that the members were not informed on the implementation progress of what they have decided or directed their leaders to do. This is against the co-operative guiding values of transparency and against the principle of education, training and information. The results below show that members were rarely being given feedback from the Board members and employed staffs (Figure 2).

The findings indicate $96 \%$ of the respondents accepted that there are no systems to provide feedback on the decision made, and its progress on implementations status. Then what actually being discussed at the General meeting is not providing the corporate decisions progress but rather presenting new ideas to get ascent from the members. In the survey the findings indicated $4 \%$ accepted that there is system of feedback provision to members. And they provided the means within which the feedback is provided. These were; meeting minutes, meeting discussion and board meeting representations. In the study done by Mbasha presented a simple question and answer that discussed the aspect of co-operative institutions whether it to belongs to members [18]. Furthermore Anania and Rwekaza contended that, the owners (co-operative members) found not being given feedback on the decision made [13]. Also the study by Kiongo found member participation being weak, mismanaged that were no feedback provided to members on decisions made [19].

The number of meetings in the co-operative institutions is not enough to surface the demand. This can be identified by evaluating the institutions that needs to have regular meetings. The board meetings were done once in two years, while it indicates that they were supposed to meet not less than two times in a year. It was observed that, members meetings were done with an average of one meeting in two years that indicate that they have years that passed without meetings of the members, on the same vein it indicates in their constitutions that they shall meet at least once in a year.

It was also found that, the meetings done, especially the annual general meeting (AGM) was done after they have been directed by the co-operative department as Government directives. It was also observed that the management meetings were not conducted at all in the surveyed agricultural marketing co-operatives. The nature of the employee that was found is temporary employees, they were employed when demand arises, and that was during harvesting period. These were the treasurer and security guard. Their nature of employment does not trigger for having management meetings. In that regard we were

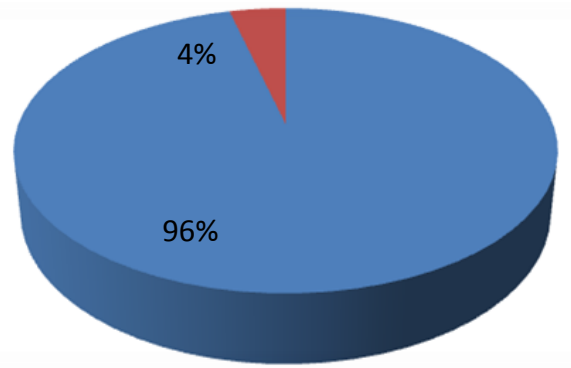

Yes

Figure 2: Feedback system to members on the decision made.

\begin{tabular}{|c|c|c|c|}
\hline S/N & $\begin{array}{c}\text { Organ in the co- } \\
\text { operative }\end{array}$ & $\begin{array}{c}\text { Average number of } \\
\text { meetings }\end{array}$ & $\begin{array}{c}\text { Total } \\
\text { respondents }\end{array}$ \\
\hline 1 & Board Meetings & 3 & 85 \\
\hline 2 & Annual General Meeting & 2.25 & 85 \\
\hline 3 & Management Meeting & 0 & 85 \\
\hline
\end{tabular}

Table 2: Meetings done from July 2011 to June 2015.

expecting to have meetings as they are indicated in the co-operative act, rules and regulations as well as the by-laws. These may indicate the areas that the co-operative institutions can exercise the action of member empowerment in broadening of participation structures. Also these would have been the area of information sharing, planning and feedback to members who are the stakeholders of these institutions (Table 2).

In trying to assess the reasons that hinders the feedback provisions, reasons provided were; absence of finances to run the meetings, absence of commitments from members, board fear to be watched on their wrong deeds and hiding of information that thought not to be provided. Its therefore indicates that there are factors that makes co-operative instructions not to have meeting the above contributions on the factors that cause co-operatives not to have meetings is the evidence that participation of members through co-operative meeting is impinged. The culture of impunity to hijack participation of members through co-operative meeting seems to be very high in the surveyed cooperatives.

\section{Conclusion and Recommendations}

\section{Conclusion}

The paper is the based on the research conducted in Shinyanga region, Tanzania. It assessed the effectiveness of the co-operative decision making structure towards enhancing sustainable co-operative organizations in the country. The co-operative members are the key stakeholders in the co-operative organizations and the aspect of members' mainstreaming in co-operative management is essential though the findings revealed the practice to be opposite in the study area. From the findings, it was clearly revealed that the aspect of member participation is not in place. The members participate by just attending the meeting, but what are their affairs in attending these meeting especially on having active participation has not reached yet. Limited participation is constrained by ignoring the power of the members in the co-operative decision making structure where members (through General assembly) have the final. This is challenging the efforts to promote actual sense of members' ownership and active participation as key stakeholders of their cooperative organizations.

\section{Recommendations}

Based on the findings used to write this paper, various issues can be recommended to improve or change the situation in the study area and other places.

(i) There is a need for capacity building on educating members on the aspects of co-operative organization structure and their functions, as well as its powers. This will increase knowledge that will eradicate the aspect of unnecessary outsiders control and develop a system of internal control.

(ii) There should be an increase of using of annual general meeting as instruments for decision making in the co-operative societies. This will enlarge the concept of member participations, and it will increase member control of their co-operative. 
Citation: Rwekaza GC, Anania P (2018) Co-operative Decision Making Structure and Its Effectiveness in Promoting Sustainable Co-operative Organizations in Tanzania: A Case of Selected Agricultural Marketing Co-operatives in Shinyanga Region. Arts Social Sci J 9: 320. doi: $10.4172 / 2151-6200.1000320$

Page 5 of 5

(iii) The systems of feedback in co-operative societies need to be indicated in their by-laws to enlarge accountability of the governing board and management to members. Reports needs to be known to members through notice boards, meetings, committees of representations and in any systems that will give the members information on what transpires in their co-operatives.

(iv) The by-laws of different co-operative societies show the aspect of meetings and these includes members meetings, board and managements, all these needs to be convened as it was scheduled. The organs in the co-operatives have to be held accountable for the act of not holding meetings as it was scheduled.

(v) The hindrance of co-operative meetings should be avoided by increasing the aspect of audits within the co-operative institutions that go beyond financial audits, to manpower audits, material audits, investments, and operational management audits to increase accountability of the administrative staffs and board to members, also to increase accountability.

(vi) There is a need to have supervisory committee in the Agricultural Marketing Co-operative Societies. The Co-operative Act of 2013 does not provide such provision, but as a matter of demand, the supervisory committees are very important to make the Board and Management accountable to members [20]. The existing Co-operative Act, Rules and Regulation need to be revised to add the concept of supervisory committee that can also make it available in the Cooperative by-laws.

\section{References}

1. Leonard MJ, Maleko GN, Mtani BT, Rwekaz GC (2013) The Power of Self Hybridization to Enhance Competitiveness and Growth: Feedback Vis-à-vis Feed Forward Philosophical Reengineering Process in Africa Weak Institutions. International journal of Development and Social Research Xavier Institute of Management Bhubaneswar. India.

2. Rwekaza GC (2013) Reflection on cooperative; Transformation and role of archives in Tanzania; cooperative transformation in Tanzania and absence of cooperative foots. International Journal of Development and Social Research Xavier Institute of Management Bhubaneswar, India.

3. Rwekaza GC, Muhihi B (2016) Cooperative development in Tanzania a too for equality and socio-economic development. Journal of economics and sustainable development. International Institute for Science Technology and Education (IISTE) London.

4. URT (2005) Ministry of cooperatives and marketing the Cooperatives Reform and Modernization Program (CRMP) Tanzania.

5. Sizya MJ (2001) The role co-operatives play in poverty reduction in Tanzania.
Paper Presented at the United Nations in observance of the International Day for the Eradication of Poverty.

6. URT (1975) Ujamaa villages Act of 1975 Dar es salaam Tanzania.

7. Komba IM (2011) Tanzania's Cooperatives in the environment of liberalized economy: Opportunities and Challenges. Cooperative Development Department Ministry of Agriculture.

8. Moshi EH (1999) Challenges of entrepreneurship and cooperative development in Tanzania. Paper presented to the annual symposium in Cooperative collage, Moshi Tanzania.

9. Chambo S (2009) Agricultural Marketing Cooperatives; Role in Food Security and Rural Development. Paper presented to expert group meeting on cooperative, New York.

10. Copa C (2010) Reaction to the European Commission's public consultation. EU Corporate Governance Framework Brussels. International Cooperative Alliance Statement on cooperative identity New Zealand cooperative association.

11. Chavez ME (2003) "Increasing productivity of rural work" UN Economic and Social Council (ECOSOC) Roundtable United Nations Headquarters New York.

12. Rwekaza GC, Nko E (2012) The hidden hands that hits cooperative development in Tanzania since independence; an analyitical note. Internationa journal of Development and Social Research Xavier Institute of Management Bhubaneswar. India.

13. Anania P, Rwekaza GC (2016) The Determinants of Success in Agricultura Marketing cooperatives in Tanzania; Experience from Mweka Sungu Mruwia and Uru North Njari Agricultural Marketing Cooperatives in Moshi District. European Journal of Research in Social Sciences, Progressive Academic Publishing, pp: 62-75.

14. Chambo S, Diyamett M (2011) Governance in Co-operatives: A study of Internal Dynamics. International Co-operative Research Conference for Africa, MUCCoBS Moshi Tanzania.

15. Solomon RJ (1999) The cooperative organization as an instrument to bring social change in rural areas. Paper presented to the annual symposium in Cooperative collage, Moshi Tanzania.

16. Mfangavo ES (1994) Community based cooperatives: A model for future cooperatives in Tanzania Paper presented to the annual symposium in Cooperative collage, Moshi Tanzania.

17. Lema SN (1997) The role of information technology in the management of the rural coffee marketing cooperative societies the case of the Kilimanjaro region. Paper presented to the annual symposium in Cooperative collage Moshi, Tanzania.

18. Mbasha JIS (1998) Ownership and participation in a cooperative enterprise Paper presented to the annual symposium in Cooperative collage, Mosh Tanzania.

19. Kiongo C (1998) Cooperative patronage in a changing environment. Paper presented to the annual symposium in Cooperative collage Moshi Tanzania.

20. URT (2013) The Cooperative Society Act of 2013. Government Printers Tanzania. 